\title{
Prevalence of iron deficiency anemia and beta thalassemia carriers among relatives of beta thalassemia patients in Nile Delta region, Egypt: a multicenter study
}

Mohamed R. El-Shanshory ${ }^{1 *}$ (D, Laila M. Sherief ${ }^{2}$, Hoda M. Hassab ${ }^{3}$, Seham M. Ragab ${ }^{4}$, Sohier Yahia ${ }^{5}$, Ahmed K. Mansour ${ }^{5}$, Adel S. Ahmed ${ }^{2}$, Said H. Abdou', Amal M. Helmy ${ }^{6}$, Mona M. Watany ${ }^{6}$, Ahmed M. Gad ALllah', Myriam A. Guindy ${ }^{8}$, Zeinab I. Mourad ${ }^{8}$, Mohamed A. Soliman ${ }^{9}$, Reham M. El-Farahaty ${ }^{10}$, Faeza El-Dahtory ${ }^{11}$, Ahmad Darwish', Suzy Abd Elmabood ${ }^{5}$, Ibrahim A. Kabbash ${ }^{12}$ and Shimaa M. Saied ${ }^{12}$

\begin{abstract}
Background: Screening of $\beta$ thalassemia among close relatives is more feasible in highly prevalent countries with limited resources. The purpose of this study is to determine the prevalence of $\beta$ thalassemia carriers and iron deficiency anemia among relatives of $\beta$ thalassemia patients in Mid Delta, Egypt.

Methods: This is a cross-sectional multi-center study conducted on 2118 relatives of patients with $\beta$ thalassemia from different Egyptian governorates in the Mid Delta region. They were subjected to history taking with precise determination of geographic location, general examination, and the following investigations: complete blood counts, serum ferritin for those who showed microcytic hypochromic anemia, and high-performance liquid chromatography for those who were not diagnosed as iron deficiency anemia.
\end{abstract}

Results: The total prevalence of iron deficiency anemia among close relatives of confirmed $\beta$ thalassemia patients in the Nile Delta region was $17.19 \%$. The highest prevalence of iron deficiency anemia (45.05\%) was reported in AlGharbia Governorate, followed by Al-Menoufia Governorate (21.67\%), and the lowest prevalence was that of AlSharkia Governorate (4.91\%). The differences were highly statistically significant $(p<0.001)$. $\beta$ thalassemia carrier prevalence rate in the studied relatives was $35.84 \%$, with the highest prevalence detected in Al-Sharkia Governorate (51.32\%), followed by Kafr-Alsheikh and Al-Dakahilia Governorates (41.78\%, 37.13\%) respectively, while Al-Menoufia Governorate had the lowest prevalence rate (25.00\%). These differences were also highly statistically significant $(p<$ 0.001).

Conclusion: More than one-third of relatives of patients with $\beta$ thalassemia are carriers of the disease, while 17.19\% suffer from iron deficiency anemia. This study demonstrates the importance of tracing the high number of beta thalassemia carriers among relatives of patients with $\beta$ thalassemia in Egypt.

Keywords: Screening, Thalassemia carriers, Mid Delta, Egypt

\footnotetext{
* Correspondence: elshanshory@gmail.com;

Mohamed.elshanshoury@med.tanta.edu.eg

${ }^{1}$ Pediatric Department, Faculty of Medicine, Tanta University, Tanta, Gharbia,

Egypt

Full list of author information is available at the end of the article
}

\section{Springer Open}

(c) The Author(s). 2021 Open Access This article is licensed under a Creative Commons Attribution 4.0 International License, which permits use, sharing, adaptation, distribution and reproduction in any medium or format, as long as you give appropriate credit to the original author(s) and the source, provide a link to the Creative Commons licence, and indicate if changes were made. The images or other third party material in this article are included in the article's Creative Commons licence, unless indicated otherwise in a credit line to the material. If material is not included in the article's Creative Commons licence and your intended use is not permitted by statutory regulation or exceeds the permitted use, you will need to obtain permission directly from the copyright holder. To view a copy of this licence, visit http://creativecommons.org/licenses/by/4.0/. 


\section{Introduction}

Thalassemia is an autosomal recessive common genetic disorder throughout the world [1]. Almost 70,000 infants are born with $\beta$ thalassemia worldwide each year [2]. Consanguineous marriages, a high fertility rate, a high birth rate, a low educational level, and early marriages, combined with an unawareness of the thalassemia problem, make developing countries to have a high number of transfusion-dependent thalassemia children in the world [3]. In general, patients with thalassemia major place a considerable burden on their families and health authorities [4].

Several countries have implemented national prevention programs, including public awareness and education, carrier screening and counseling, and information on the prenatal and pre-implantation diagnosis of the disease [5]. Carrier screening has had great success, leading to a decline in the birth rate of thalassemia major in some countries [5]. It has been estimated that one thousand children out of 1.5 million live births are born each year suffering from thalassemia in Egypt [6]. It is reported that the carrier rate in Egypt is between 9 to $10 \%$ of the population [7].

In Egypt, despite the high prevalence of $\beta$ thalassemia carriers and the growing number of patients born each year, there is no national thalassemia prevention program [8]. Few studies were performed to assess the carrier rate of $\beta$ thalassemia $[9,10]$. Selective screening approach within the families suffering from thalassemia is ideal and more feasible in highly prevalent regions with limited resources. The aim of our study was to determine $\beta$ thalassemia carriers, in addition to iron deficiency anemia, individuals among relatives of $\beta$ thalassemia patients, especially in population crowded regions, for raising the awareness of the problem among this high-risk population.

\section{Methods}

\subsection{Study design and setting}

The current study is a cross-sectional multi-center study conducted on 2118 relatives of patients with $\beta$ thalassemia from different Egyptian governorates in the Mid Delta region (Al-Gharbia, Al-Dakahlia, Al-Menuofiea, Al-Sharkhia, Kafer el-Sheikh, Al-Beheira, and Alexandria).

\subsection{Participants}

The study participants represented respondents who were eligible and agreed to participate in the study from the relatives ( $2 \mathrm{nd}, 3 \mathrm{rd}$, and 4th degree) of all known $\beta$ thalassemic children attending hematology/oncology clinics at Tanta, Zagazig, Mansoura, Menuofia, and Alexandria Universities' Hospitals during the 48 months of the study (from 2016-2020). According to Egyptian law, brothers and sisters are considered second degree relatives. Grandparents, grandchildren, aunts, uncles, nieces, and nephews are considered third degree relatives, and cousins are considered fourth degree relatives. The study population included 963 male and 1155 female. The excluded relatives were those with other hemolytic anemia, relatives of known $\alpha$ thalassemic patients, and parents of $\beta$ thalassemic patients.

\subsection{Data collection}

All the individuals included in the study were subjected to full history taking, thorough clinical examination, and the following investigations: complete blood count (CBC) by automated ABX PENTRA XL80 device. The cut-off level for hemoglobin used to classify subjects into anemic and non-anemic; the hemoglobin level less than $11 \mathrm{~g} / \mathrm{dl}$ in the age group between 6 and 12 years [11], and hemoglobin level $<13 \mathrm{~g} / \mathrm{dl}$ in male and $<12 \mathrm{~g} / \mathrm{dl}$ in female in the age group more than 12 years [12]. Mean corpuscular volume (MCV) of less than $80 \mathrm{fl}$ and/or mean corpuscular hemoglobin $(\mathrm{MCH})$ of less than $27 \mathrm{pg}$ are generally used as cut-off points for further screening with serum ferritin to exclude iron deficiency anemia. Serum ferritin less than $15 \mathrm{ng} / \mathrm{ml}$ is considered diagnostic of iron deficiency [13]. Blood samples of participants with normal serum ferritin were analyzed by high performance liquid chromatography (HPLC) for quantitative estimation of an elevated HbA2 level, using the hemoglobin analyzer ARKRAY ADAMS A1C HA-8180T (Japan) device. HbA2 < 3.5\% is considered diagnostic of $\beta$ thalassemia carrier state [14].

\subsubsection{Sample collection and storage}

Five milliliters of whole blood were collected from every subject into three vacutainer tubes. The first tube containing EDTA was used as an anticoagulant for a complete blood picture $(\mathrm{CBC})$ and $2 \mathrm{~mm}$ into a second tube for high performance liquid chromatography (HPLC). The third tube was used for serum ferritin measurement for participants with hypochromic microcytic anemia.

\subsection{Statistical analysis of data}

The collected data were coded, verified for completeness, recorded in a Microsoft Excel master sheet, and then statistically analyzed utilizing the SPSS ${ }^{\mathrm{rm}}$ (Statistics Program for Social Studies) software version 25 produced by IBM, Chicago, IL, USA. Means and standard deviations were used to describe numerical values, while frequencies were used for categorical ones.

The Chi-square test was used to test the differences between categorical variables, while the Mann-Whitney $U$ test was used for independent quantitative variables. $P$ 
value was considered significant at $<0.05$ and $<0.001$ for highly significant results.

\section{Results}

Figure 1 shows the screening algorism among the close relatives of patients with confirmed $\beta$ thalassemia. The total number of participants in this study was 2118 children. Males constituted 936 participants (45.47\%) while $54.53 \%$ (1155) were females. Participants with hypochromic microcytic anemia constituted 1123 (53.02\%).

Table 1 illustrates the prevalence of iron deficiency anemia and $\beta$ thalassemia carriers among the study

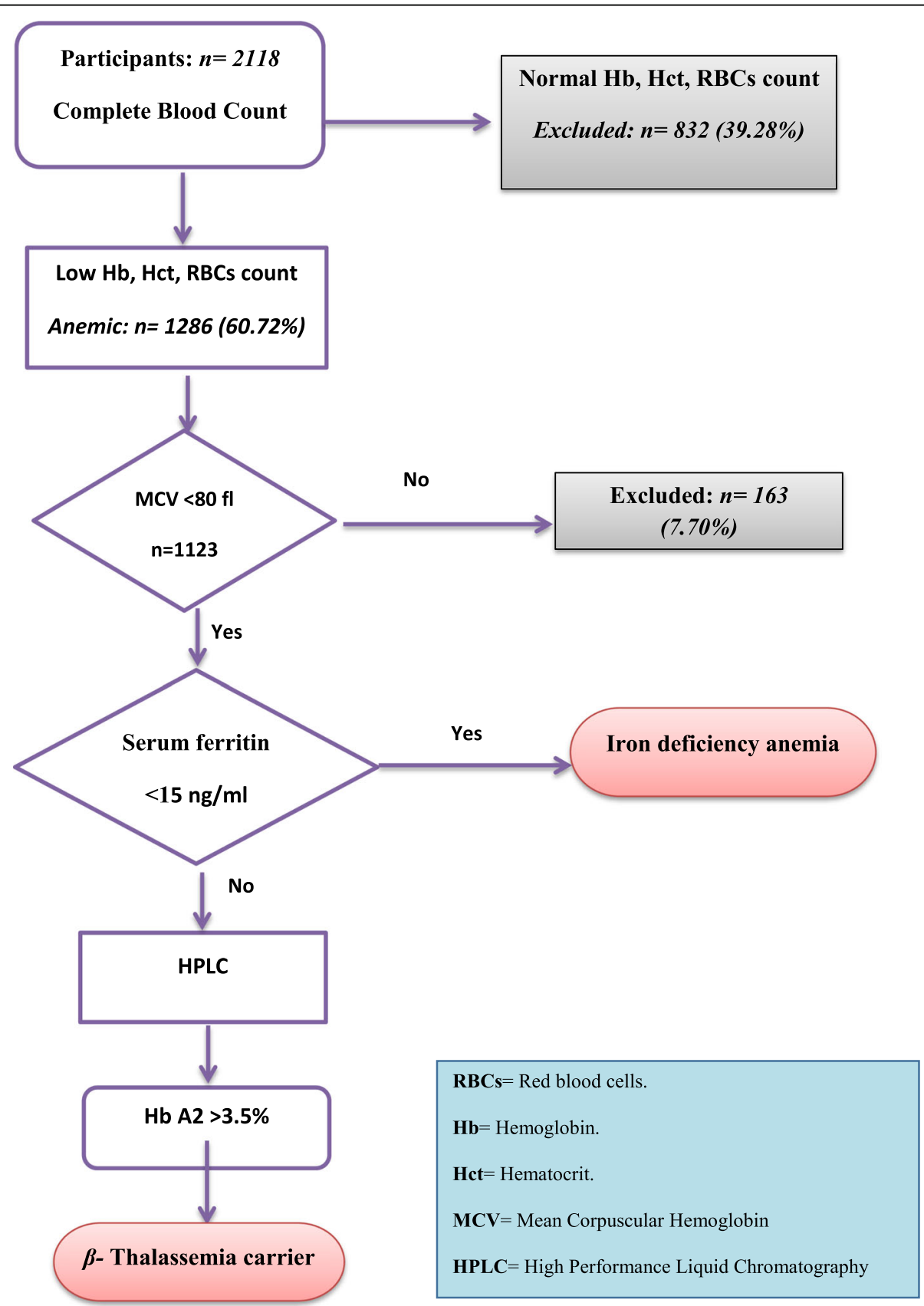

Screening algorithm for the participants

Fig. 1 Screening algorithm for the participants 
Table 1 Prevalence of iron deficiency anemia and $\beta$ thalassemia carriers among studied relatives in Mid Nile Delta Egyptian Governorates (2016-2020)

\begin{tabular}{|c|c|c|c|c|c|}
\hline \multirow[t]{2}{*}{ Governorate } & \multirow{2}{*}{$\begin{array}{l}\text { Total examined } \\
N\end{array}$} & \multicolumn{2}{|c|}{$\begin{array}{l}\text { Iron deficiency anemia } \\
\text { (Group 1) }\end{array}$} & \multicolumn{2}{|c|}{$\begin{array}{l}\beta \text { thalassemia carrier } \\
\text { (Group 2) }\end{array}$} \\
\hline & & $N$ & $\%$ & $N$ & $\%$ \\
\hline Al-Gharbia & 182 & 82 & 45.05 & 56 & 30.77 \\
\hline Al-Menoufia & 300 & 65 & 21.67 & 75 & 25.00 \\
\hline Al-Sharkia & 265 & 13 & 4.91 & 136 & 51.32 \\
\hline Al-Dakahilia & 668 & 100 & 14.97 & 248 & 37.13 \\
\hline Al-Beihera & 219 & 22 & 10.05 & 70 & 31.96 \\
\hline Alexandria & 326 & 69 & 21.17 & 108 & 33.13 \\
\hline Kafr-Elsheikh & 158 & 13 & 8.23 & 66 & 41.78 \\
\hline Total & 2118 & 364 & 17.19 & 759 & 35.84 \\
\hline$x^{2}$ & 154.32 & & & 50.36 & \\
\hline$P$ & $<0.001^{* *}$ & & & $0.001^{* *}$ & \\
\hline
\end{tabular}

**Highly significant $(P<0.01)$

participants in relation to the governorate of residence. The total prevalence of iron deficiency anemia among close relatives of confirmed $\beta$ thalassemia patients in the Nile Delta region was found to be $17.19 \%$. The highest prevalence of iron deficiency anemia (45.05\%) was reported in $\mathrm{Al}$ Gharbia Governorate, followed by Al-Menoufia Governorate $(21.67 \%)$ and the lowest prevalence was that of $\mathrm{Al}$ Sharkia Governorates (4.91\%), these differences were highly statistically significant $(p<0.001)$. On the other hand, the total carrier prevalence rate in the studied relatives was $35.84 \%$, with the highest prevalence detected in $\mathrm{Al}$-Sharkia Governorates (51.32\%), followed by Kafr-Alsheikh Governorate (41.78\%), and Al-Dakahilia (37.13\%). Al-Menoufia Governorate had the lowest prevalence rate (25.00\%). These differences were also found highly statistically significant $(p$ $<0.001)$.

Table 2 demonstrates a comparison of blood indices between $\beta$ thalassemia carriers and iron deficiency anemia of the studied relatives. Only hemoglobin concentration showed no significant difference between the two groups $(p=0.152)$. The total number of red blood corpuscles among group $2(5.28 \pm 0.63) \times 10^{6} / \mathrm{mm}^{3}$ was significantly higher than that recorded for children with the group $1(3.74 \pm 0.56) \times 10^{6} / \mathrm{mm}^{3}(p=0.001)$. The mean hematocrit percentage in group $2(33.31 \pm 4.09) \%$ was significantly higher than that of group 1 (32.7 \pm 3.71) $(p=0.001)$. Besides, mean corpuscular volume was significantly higher among group $1(67.83 \pm 7.21) \mathrm{fl}$ compared to group $2(62.42 \pm 6.37) \mathrm{fl}(p=0.001)$. The same applies for $\mathrm{MCH}, 22.70 \pm 2.81$ versus $20.32 \pm 2.21$ $\mathrm{pg}(p=0.001) ; \mathrm{MCHC}, 33.94 \pm 2.32 \mathrm{~g} / \mathrm{dl}$ versus $32.83 \pm$ $2.31 \mathrm{~g} / \mathrm{dl}(p=0.001)$.

Lastly, group 1 had a significantly higher mean red cell distribution width, $16.89 \pm 2.28 \%$, compared to $15.30 \pm$ $2.18 \%$ for group $2(p=0.001)$.
Table 3 shows the comparison of serum ferritin and $\mathrm{HbA} 2 \%$ between relatives who are $\beta$ thalassemia carriers and those with iron deficiency anemia. Serum ferritin shows a significantly lower mean of $8.20 \pm 3.78 \mathrm{ng} / \mathrm{ml}$ among group 1 than $68.73 \pm 49.33 \mathrm{ng} / \mathrm{ml}$ among group $2(p=0.001)$. In comparison, the group's 2 hemoglobin A2\% was significantly higher $(4.55 \pm 0.5) \%$ compared to the mean of $2.54 \pm 0.49 \%$ detected among group $2(p<$ $0.001)$.

\section{Discussion}

Symptomatic $\beta$ thalassemia syndromes constitute a significant public health problem in Egypt; the high prevalence of beta thalassemia carriers, combined with a growing number of newly born cases, underscores the critical significance of developing a beta thalassemia prevention program in Egypt [15]. Prevention by carrier detection is needed in populations with a high incidence of the disease, such as Egypt. Improving public awareness and mandatory premarital screening for carrier detection are essential to offer prenatal diagnosis and genetic counseling for high-risk couples [15].

Various approaches of carrier screening programs were conducted in several countries. They include general population screening, high-risk group screening, antenatal screening, and cascade screening or extended family screening [16]. As an autosomal recessive disease, together with the high rate of consanguineous marriages in our country, the expected highest prevalence of $\beta$ thalassemia carriers will be among the patient's relatives who are a good target for screening. This type of screening may offer an alternative to population screening for identifying present and future couples at risk for producing affected children [17]. 
Table 2 Complete blood count of $\beta$ thalassemia carriers and iron deficiency anemia participants in Mid Nile Delta Egyptian Governorates (2016-2020)

\begin{tabular}{|c|c|c|c|c|c|}
\hline Variable & & $\begin{array}{l}\text { Iron deficiency anemia } \\
\text { (Group 1) }\end{array}$ & $\begin{array}{l}\beta \text { thalassemia carrier } \\
\text { (Group 2) }\end{array}$ & $\mathrm{MW}^{\#}$ & $P$ \\
\hline \multirow[t]{3}{*}{ Red blood corpuscles $\left(\mathrm{X} 10^{6} / \mathrm{mm}^{3}\right)$} & Mean $\pm S D$ & $3.74 \pm 0.56$ & $5.28 \pm 0.63$ & 13.45 & $0.001^{* *}$ \\
\hline & Range & $2.30-4.96$ & $4.00-6.60$ & & \\
\hline & Median & 3.80 & 5.28 & & \\
\hline \multirow[t]{3}{*}{ Hemoglobin (g/dl) } & Mean $\pm S D$ & $10.60 \pm 1.21$ & $10.95 \pm 1.20$ & 1.43 & 0.152 \\
\hline & Range & $6.60-12.90$ & $9-15.40$ & & \\
\hline & Median & 10.80 & 10.90 & & \\
\hline Hematocrit value (\%) & $\begin{array}{l}\text { Mean } \pm S D \\
\text { Range } \\
\text { Median }\end{array}$ & $\begin{array}{l}32.7 \pm 3.71 \\
18.50-39.7 \\
32.70\end{array}$ & $\begin{array}{l}33.31 \pm 4.09 \\
20.20-44.90 \\
33.10\end{array}$ & 2.34 & $0.019^{* *}$ \\
\hline \multirow[t]{3}{*}{ Mean corpuscular volume (fl) } & Mean $\pm S D$ & $67.83 \pm 7.21$ & $62.42 \pm 6.37$ & 7.70 & $0.001^{* *}$ \\
\hline & Range & $45-79$ & $45.0-79.0$ & & \\
\hline & Median & 69.00 & 62.00 & & \\
\hline \multirow[t]{3}{*}{ Mean corpuscular hemoglobin (pg) } & Mean $\pm S D$ & $22.70 \pm 2.81$ & $20.32 \pm 2.21$ & 7.20 & $0.001^{* *}$ \\
\hline & Range & $14.60-27$ & $15.20-27.20$ & & \\
\hline & Median & 22.75 & 20.10 & & \\
\hline \multirow[t]{3}{*}{ Mean corpuscular hemoglobin concentration ( $\mathrm{g} / \mathrm{dl}$ ) } & Mean $\pm S D$ & $33.94 \pm 2.32$ & $32.83 \pm 2.31$ & 3.95 & $0.001^{* *}$ \\
\hline & Range & $29.50-38.20$ & $26.80-37.80$ & & \\
\hline & Median & 34.00 & 32.30 & & \\
\hline \multirow[t]{3}{*}{ Red cell distribution width (\%) } & Mean $\pm S D$ & $16.89 \pm 2.28$ & $15.30 \pm 2.18$ & 5.93 & $0.001^{* *}$ \\
\hline & Range & $11.90-21.30$ & $11.00-18.40$ & & \\
\hline & Median & 17.4 & 16.00 & & \\
\hline
\end{tabular}

$S D$ standard deviation

"MW: $Z$ value of Mann-Whitney $U$ test

**Highly significant $(P<0.01)$

The current study involved 2118 relatives of patients with $\beta$ thalassemia from different Egyptian governorates in the Mid Delta region. Microcytic hypochromic anemia was diagnosed in $53.02 \%$ of the studied groups. Carrier detection in this study was based upon the presence of microcytic hypochromic anemia, normal serum ferritin level together with HbA2 level of < 3.5\% [14].

$\beta$ thalassemia carrier state constituted the majority among children with microcytic hypochromic anemia
(67.59\%), with a prevalence rate of $35.84 \%$ among the studied relatives of the patients. This is about 3-4 times higher than the estimated carrier rate of $9-10 \%$ in the general population [7]. This result supports what was previously reported that $\beta$ thalassemia carriers are more prevalent in siblings of thalassemia major than the normal population [18]. Most of the previous studies included general population and pregnant women screening, with few that included relatives of thalassemia

Table 3 Serum ferritin and HbA2 of $\beta$ thalassemia carriers and iron deficiency anemia participants Mid Nile Delta Egyptian Governorates (2016-2020)

\begin{tabular}{|c|c|c|c|c|c|}
\hline Variable & & $\begin{array}{l}\text { Iron deficiency anemia } \\
\text { (Group 1) }\end{array}$ & $\begin{array}{l}\beta \text { - thalassemia carrier } \\
\text { (Group 2) }\end{array}$ & $\mathrm{MW}^{\#}$ & $P$ \\
\hline \multirow[t]{3}{*}{ Serum ferritin $(\mathrm{ng} / \mathrm{ml})$} & Mean $\pm S D$ & $8.20 \pm 3.78$ & $68.73 \pm 49.33$ & 23.35 & $0.001^{* * *}$ \\
\hline & Range & $1.00-14.90$ & $15.50-349$ & & \\
\hline & Median & 6.85 & 55.00 & & \\
\hline \multirow[t]{3}{*}{ Hemoglobin A2\% } & Mean $\pm S D$ & $2.54 \pm 0.49$ & $4.50 \pm 0.59$ & 23.36 & $0.001^{* *}$ \\
\hline & Range & $1.30-3.40$ & $3.60-6.99$ & & \\
\hline & Median & 2.60 & 4.500 & & \\
\hline
\end{tabular}

$S D$ standard deviation

"MW: $Z$ value of Mann-Whitney $U$ test

**Highly significant $(P<0.01)$ 
patients. To our knowledge, there is no published data about similar studies in Egypt.

Our estimated prevalence of $\beta$ thalassemia trait ( $\beta \mathrm{TT}$ ) in relatives of patients is nearly similar to what was reported in Rawalpind, Pakistan (31\%) by Ahmed et al. [19] while it is higher than the prevalence reported by Gorakshakar and Colah (21.9\%) in extended family screening in India [17]. On the other hand, it is lower than what was found in other studies done in Faisalabad (44.4\%) [20], Kota (48.76\%) [18], Bandung (59.6\%) [21], Karachi (62.2\%) [22], Bhopal (76\%) [23], and North India (76.92\%) [24]. This discrepancy could be explained by the differences in general prevalence rate in the geographic areas involved, selection criteria in each study (siblings only or extended family, the number of included individuals), and genetic heterogeneity of thalassemia gene.

In this study, the highest carrier prevalence rate was detected in Al-Sharkia Governorates and followed by Kafr-Alsheikh Governorate, Al-Dakahilia, while AlMenoufia Governorate had the lowest prevalence rate. This variation between localities might be related to the different rate of consanguineous marriage in different Egyptian communities. In societies where the majority of couples are unrelated, genes for recessive disorders usually run in families for many generations without manifesting through the birth of an affected child. By contrast, gene variants are trapped within extended family members [19]. Thus, in communities where consanguinity is evident, one can identify even more carriers [16]. It was reported that the cascade screening result was more impressive in a small location.

For example, in Sardinia, by analyzing $11 \%$ of the population, more than $90 \%$ of the "at risk" couples were detected [25]. An affected child is a predictor of high genetic risk, and an extended family study may discover several carriers and couples at risk before marriage or reproduction [17]. Family studies provide a highly effective risk detection approach. Population screening is less effective, but carrier follow-up will detect elevated risk prior to any affected child's birth. Moreover, the perfect approach is to provide both family studies and premarital or antenatal screening for the relatives of affected children [19].

Worldwide, beta thalassemia trait ( $\beta \mathrm{TT})$ and iron deficiency anemia (IDA) are the two most frequent causes of microcytic anemia [26]. The differentiation between IDA and $\beta$ TT is of prime importance, especially in these high-risk groups for being $\beta T$ carriers [27]. Iron deficiency anemia is of high prevalence among Egyptian children. In the study performed by El-Beshlawy et al. [9], about one-third of the studied population in upper \& lower Egypt had IDA based on the presence of microcytic hypochromic anemia with serum ferritin level below $15 \mathrm{ng} / \mathrm{ml}$. In the present study, IDA was diagnosed in $17.19 \%$ of the participants. Though lower than what was estimated in the general population, IDA is prevalent among relatives of thalassemia patients and should be searched for and adequately treated. The highest prevalence of IDA (45.05\%) was reported in $\mathrm{Al}$ Gharbia Governorate, followed by Al-Menoufia Governorate (21.67\%), and the lowest prevalence was that of Al-Sharkia Governorates (4.91\%). The significant difference between different governorates could be related to the involvement of rural areas in governorates with a high prevalence of IDA, lower-income families with limited access to iron-rich foods, and inefficient utilization of available micronutrients as a result of infectious diseases, particularly helminthic infections [28].

Comparing the hematological parameters of relatives with $\beta$ TT and those with IDA, no significant difference was found regarding $\mathrm{Hb}$ level. In contrast, $\beta \mathrm{TT}$ relatives had a significantly higher RBCs count, with significant lower $\mathrm{MCV}, \mathrm{MCH}, \mathrm{MCHC}$, and RDW than IDA. Red blood cell (RBC) count is known to be increased in both thalassemia patients and carriers. It is considered a useful diagnostic adjunct because thalassemia has microcytic anemia, increasing the RBCs number. In contrast, other causes of microcytic anemias, including iron deficiency anemia and anemia of chronic disease, are typically associated with a proportional decrease in the RBC number [29].

In accordance with our results, a high RBC count among BTT was reported by Demir et al. [30], Vehapoglu et al. [27], and Jameel et al. [31]. Demir et al. [30] reported that RBC count is one of the most reliable discrimination indices in differentiation between $\beta \mathrm{TT}$ and IDA, with $90 \%$ of the patients were correctly identified with RBC count. The majority of $\beta$ thalassaemia carriers have reduced $\mathrm{MCV}$ and $\mathrm{MCH}$ levels in the standard complete blood examination (FBE) [31]. Low $\mathrm{MCV}$ is the key indicator for diagnosis and screening for thalassemia. It was suggested that an $\mathrm{MCV}$ of $<72$ is maximally sensitive and specific for the presumptive diagnosis of thalassemia [32].

The red cell distribution width (RDW) index reflects the heterogeneity in the size distribution of erythrocytes, measuring the coefficient of variation around MCV [33]. It was found to be the most reliable index evaluated for discrimination between $\beta$ TT and IDA, with $100 \%$ sensitivity and $92.6 \%$ specificity. This index can be used to efficiently screen patients with microcytosis for further hematologic studies to confirm $\beta$ thalassemia [34].

Normal RDW among $\beta$ TT was also reported by other studies $[18,35,36]$. So, microcytosis accompanied by a high RBC count and normal RDW is highly suggestive of BTT [36]. A definitive differential diagnosis between $\beta \mathrm{TT}$ and IDA is based on HbA2 electrophoresis, serum 
iron, and ferritin levels [37]. In this regard, relatives of thalassemia patients with $\beta$ TT have a significantly higher level of HbA2 with significantly higher serum ferritin levels than those diagnosed as IDA. HbA2 levels (> $3.5 \%)$ are the most significant parameter for identifying beta thalassemia carriers [28]. In this study, those with BTT have HbA2 ranged between $3.60-6.99 \%$ with a mean value of $4.55 \pm 0.59 \%$. In similar studies, the mean $\mathrm{HbA} 2 \%$ levels were $11.93 \pm 0.5 \%$ [21], $4.99 \pm 0.64 \%$ [16], and $5.24 \pm 1.14 \%[18]$.

\subsection{Limitations of the study}

An important limitation is the unavailability of molecular diagnosis of thalassemia and genetic screening to determine the genetic profile for individuals to identify carriers. Besides, carrier identification by premarital and/ or early antenatal thalassemia screening is not mandatory and is not commonly used in Egypt. As the current state of thalassemia reflects the increasing need for national preventive program to reduce morbidity and mortality associated with this disease, particularly given the country's limited resources and that thalassemia prevention is cost-effective. We recommend initiating a national program for extended family screening of relatives with beta thalassemia patients as a preparatory and promising step to establish a national prevention program utilizing the data collected from the screening.

\section{Conclusion}

Thalassemia carriers have characteristic hematological parameters with mild anemia with microcytic hypochromic RBCs, increased red cell counts and normal RDW that could help screening and together with $\mathrm{HbA} 2$ quantification by $\mathrm{Hb}$ electrophoresis or HPLC, $\beta \mathrm{TT}$ can be easily diagnosed and screened for in high-risk groups like family members and relatives of thalassemia patients. Family screening program by screening for microcytic hypochromic anemia with increased RBCs reduced $\mathrm{MCV} ; \mathrm{MCH}$ and normal RDW is a valuable and feasible alternative to the population screening for detecting family members at risk of carrier state of $\beta \mathrm{TT}$. Those can be further identified by measuring $\mathrm{HbA} 2$.

\section{Abbreviations \\ BTT: $\beta$ thalassemia trait; CBC: Complete blood count; \\ EDTA: Ethylenediaminetetraacetic acid; FBE: Full blood examination; Hb: Hemoglobin; HPLC: High performance liquid chromatography; IDA: Iron deficiency anemia; MCH: Mean corpuscular hemoglobin; MCHC: Mean corpuscular hemoglobin concentration; MCV: Mean corpuscular volume; NTDT: Non-transfusion-dependent $\beta$ thalassemia; RBCs: Red blood cells; RDW: Red cell distribution width; SPSS: Statistics Program for Social Studies; TDT: Transfusion-dependent $\beta$ thalassemia}

\section{Acknowledgements}

The authors would like to thank all of the subjects who participated in this study and acknowledge all of the study investigators (Abdelwahab Abukhadra; Yahia S Abdou; Sameh A Abdel Naby; Zein A Omar; Eman Y Amer; Amr M Nassar; Noha M Khames; Ahmed El-Said; Ahmed F Abu Shosha;
Haidy M Ibrahim; Dalia M Abd Elwahab; Reham F El- Moghazy; Lamia M Morad; Sara S Allam; Osama M Hussien) who share in the data collection. Lastly, we would like to thank, the Science, Technology, and Development Fund (STDF) for the support and establishment of the Delta Thalassemia Center: Control and Prevention.

\section{Authors' contributions}

This research was carried out in collaboration with all authors. Conceptualization: ME, LS, SY, SR, AM, HH, SA, AA, AD, and SE. Methodology: $A H, M W, Z M, M G, A A, M S, F E, R E$, IK, and SS. Formal analysis and investigation: $M E, L S, S Y, S R, A H, A A, M S$, and IK. Writing-original draft preparation: SY, SR, AH; YA, and SS. Writing - revision and editing: ME, LS, and SS. All authors read and approved the final manuscript.

\section{Funding}

This work was supported by the Science, Technology, and Development Fund (STDF) [Capacity building Grant Project number 12439].

\section{Availability of data and materials}

The research data is available upon a reasonable request to the corresponding author.

\section{Declarations}

Ethics approval and consent to participate

The experimental protocol for involving humans was following the national/ international/institutional boards and the Declaration of Helsinki. The Ethics Committee of the Faculty of Medicine, Tanta University approved the study, with a reference code number (3031/01/15). A written informed consent was taken from each study participant. Confidentiality of participants' information was guaranteed.

\section{Consent for publication \\ Not applicable.}

\section{Competing interests}

The authors declare no competing interests.

\section{Author details \\ ${ }^{1}$ Pediatric Department, Faculty of Medicine, Tanta University, Tanta, Gharbia, Egypt. ${ }^{2}$ Pediatric Department, Faculty of Medicine, Zagazig University, Zagazig, Egypt. ${ }^{3}$ Pediatric Department, Faculty of Medicine, Alexandria University, Alexandria, Egypt. ${ }^{4}$ Pediatric Department, Faculty of Medicine, Menoufia University, Shibin el Kom, Egypt. ${ }^{5}$ Pediatric Department, Faculty of Medicine, Mansoura University, Mansoura, Egypt. ${ }^{6} \mathrm{Clinical}$ Pathology Department, Faculty of Medicine, Tanta University, Tanta, Egypt. ${ }^{7}$ Clinical Pathology Department, Faculty of Medicine, Zagazig University, Zagazig, Egypt. ${ }^{8} \mathrm{Clinical}$ and Chemical Pathology Department, Faculty of Medicine, Alexandria University, Alexandria, Egypt. ${ }^{9}$ Clinical Pathology Department, Faculty of Medicine, Menoufia University, Shibin el Kom, Egypt. ${ }^{10} \mathrm{Clinical}$ Pathology Department, Faculty of Medicine, Mansoura University, Mansoura, Egypt. ${ }^{11}$ Consultant of Biochemistry, Genetic Unit, Children Hospital, Mansoura University, Mansoura, Egypt. ${ }^{12}$ Public Health and Community Medicine Department, Faculty of Medicine, Tanta University, Tanta, Egypt.}

Received: 31 October 2020 Accepted: 16 August 2021

Published online: 11 October 2021

\section{References}

1. Weatherall DJ, Clegg JB. The thalassaemia syndromes: fourth edition. Oxford: Blackwell Science Ltd.; 2001. https://doi.org/10.1002/9780470696705.

2. Abolghasemi H, Amid A, Zeinali S, Radfar MH, Eshghi P, Rahiminejad MS, et al. Thalassemia in Iran: epidemiology, prevention, and management. J Pediatr Hematol Oncol. 2007;29(4):233-8. https://doi.org/10.1097/MPH.0b013 e3180437e02.

3. Raza S, Faroogi S, Shoaib MW, Jabeen S. Beta thalassemia: prevalence, risk and challenges. Int J Med Heal Res. 2016;1:5-7.

4. Lai K, Huang G, Su L, He Y. The prevalence of thalassemia in mainland China: evidence from epidemiological surveys. Sci Rep. 2017;7:920. https:// doi.org/10.1038/s41598-017-00967-2. 
5. Cao A, Kan YW. The prevention of thalassemia. Cold Spring Harb Perspect Med. 2013;1(2):3. https://doi.org/10.1101/cshperspect.a011775.

6. El-Hashemite N, Petrou M, Khalifa AS, Heshmat NM, Rady MS, Delhanty JD. Identification of novel Asian Indian and Japanese mutations causing $\beta$ thalassaemia in the Egyptian population. Hum Genet. 1997;99(2):271-4. https://doi.org/10.1007/s004390050352.

7. El-Beshlawy A, Kaddah N, Ragab L, Hussein I, Mouktar G, Moustafa A, et al. Thalassemic prevalence and status in Egypt. Abstract 102. In: Proceedings of The Annual Meeting of the American Pediatric Society. San Francisco; 1999.

8. Elgawhary S, Elbaradie Sahar MY, Rashad WM, Abdallah MAH, Ezzat G, et al. Prenatal diagnosis of beta-thalassemia in Egypt: implementing accurate high-tech methods did not reflect much on the outcome. Pediatr Hematol Oncol. 2008;25(6):541-8. https://doi.org/10.1080/ 08880010802313509.

9. El-Beshlawy A, Kaddah N, Ragab L, Hussein I, Mouktar G, Moustafa A, et al. Screening for B-thalassaemia carriers in Egypt: significance of the osmotic fragility test. East Mediterr Health J. 2007;13(4):780-6.

10. Abdel-Messih IY, Youssef SR, Mokhtar GM, Elmogy MI, Mahmoud HM, Ayoub $\mathrm{M}$, et al. Clinical to molecular screening paradigm for $\beta$-thalassemia carriers. Hemoglobin. 2015;39(4):240-6. https://doi.org/10.3109/03630269.2015.104 8808.

11. Barbara J, Imelda B, Mike A. Laboratory methods used in the investigation of the haemolytic anaemias. In: Dacie and Lewis Practical Hematology Book, vol. 11. 12th ed: Elsevier; 2016. p. 229-44.

12. van Vranken M. Evaluation of microcytosis. Am Fam Physician. 2010;82(9): 1117-22. https://www.aafp.org/afp/2010/1101/p1117.htm.

13. WHO, CDC (2007) Assessing the iron status of populations: including literature reviews. Report of a Joint World Health Organization/Centers for Disease Control and Prevention Technical Consultation on the assessment of iron status at the population level, Geneva, Switzerland. 2nd edition. Geneva: WHO/CDC; 2004.

14. Galanello R, Origa R. Open access REVIEW BioMed Central beta-thalassemia. Orphanet J Rare Dis. 2010;5(1):11. https://doi.org/10.1186/1750-1172-5-11.

15. El-Beshlawy A, Youssry I. Prevention of hemoglobinopathies in Egypt. Hemoglobin. 2009;33(Suppl 1):S14-20. https://doi.org/10.3109/036302 60903346395

16. Gorakshakar AC, Colah RB. Cascade screening for $\beta$-thalassemia: a practical approach for identifying and counseling carriers in India. Indian J Community Med. 2009;34(4):354-6. https://doi.org/10.4103/0970-0218.58399.

17. Alwan A, Modell B. Community control of genetic and congenital disorders EMRO technical publication series 24. Alexandria: WHO Regional Office for the Eastern Mediterranean; 1997.

18. Sharma G, Sharma D, Gulati RK. Thalassemia carrier screening in siblings of thalassemia major patients by HbA2 estimation. Indian J Child Health. 2016; 3(3):258-60. https://doi.org/10.32677/JJCH.2016.v03.103.020.

19. Ahmed S, Saleem M, Modell B, Petrou M. Screening extended families for genetic hemoglobin disorders in Pakistan. N Engl J Med. 2002;347(15):11628. https://doi.org/10.1056/NEJMsa013234.

20. Baig SM, Din MA, Hassan H, Azhar A, Baig JM, Aslam M, et al. Prevention of $\beta$-thalassemia in a large Pakistani family through cascade testing. Comm Genet. 2008;11(1):68-70. https://doi.org/10.1159/000111641.

21. Maskoen AM, Reniarti L, Sahiratmadja E, Sisca J, Effendi SH. Shine \& Lal index as a predictor for early detection of $\beta$-thalassemia carriers in a limited resource area in Bandung, Indonesia. BMC Med Genet. 2019;20(1):136. https://doi.org/10.1186/s12881-019-0868-x.

22. Ansari SH, Shamsi TS, Baig N, Ansari ZH, Perveen K, Erum S, et al. Screening immediate family members for carrier identification and counseling: a costeffective and practical approach. J Pak Med Assoc. 2012;62(12):1314-7.

23. Mishra AK, Tiwari A. Screening and molecular characterization of $\beta$ thalassaemia mutations in parents and siblings of thalassaemia major patients. Int J Biomed Res. 2014;3(2):481-6. https://doi.org/10.7439/ijbr.v5i2.4 59.

24. Piplani S, Manan R, Lalit M, Manjari M, Bhasin T, Bawa J. NESTROFT - a valuable, cost effective screening test for beta thalassemia trait in north Indian Punjabi population. J Clin Diagn Res. 2013;7(12):2784-7. https://doi. org/10.7860/JCDR/2013/6834.3759.

25. Cao A, Galanello R. Effect of consanguinity on screening for thalassemia. N Engl J Med. 2002;347(15):1200-2.

26. Rahim F, Keikhaei B. Better differential diagnosis of iron deficiency anemia from beta-thalassemia trait. Turkish J Hematol. 2009:26(3):138-45.
27. Vehapoglu A, Ozgurhan G, Demir AD, Uzuner S, Nursoy MA, Turkmen S, et al. Hematological indices for differential diagnosis of beta thalassemia trait and iron deficiency anemia. Anemia. 2014;2014:576738-42. https://doi. org/10.1155/2014/576738

28. Asobayire FS, Adou P, Davidsson L, Cook JD, Hurrell RF. Prevalence of iron deficiency with and without concurrent anemia in population groups with high prevalences of malaria and other infections: a study in Côte d'Ivoire1-3. Am J Clin Nutr. 2001;74(6):776-82. https://doi.org/10.1093/ajcn/74.6.776.

29. Panda A, Praveen B, Bisht SS. Clinical and pathological status of haemoglobinopathies among pregnant women in southern Orissa. Indian J Biotechnol. 2009:8(4):456-7.

30. Demir A, Yarali N, Fisgin T, Duru F, Kara A. Most reliable indices in differentiation between thalassemia trait and iron deficiency anemia. Pediatr Int. 2002;44(6):612-6. https://doi.org/10.1046/j.1442-200X.2002.01636.x.

31. Jameel T, Baig M, Ahmed I, Hussain MB, Alkhamaly MBD. Differentiation of beta thalassemia trait from iron deficiency anemia by hematological indices. Pakistan J Med Sci. 2017;33(3):665-9.

32. Tyagi S, Dass J, Sharma M. Diagnosis of thalassemia and haemoglobinopathies. In: Agarwal MB, editor. Haematology Today. Mumbai: Agarwal Publisher; 2010. p. 91-101.

33. Trent RJA. Diagnosis of the haemoglobinopathies. Clin Biochem Rev. 2006; 27(1):27-38.

34. Urrechaga E, Borque L, Escanero JF. The role of automated measurement of RBC subpopulations in differential diagnosis of microcytic anemia and $\beta$ thalassemia screening. Am J Clin Pathol. 2011;135(3):374-9. https://doi.org/1 0.1111/.1751-553X.2010.01237.x.

35. Bessman JD, Feinstein DI. Quantitative anisocytosis as a discriminant between iron deficiency and thalassemia minor. Blood. 1979;53(2):288-93. https://doi.org/10.1182/blood.V53.2.288.288.

36. Parthasarathy V. A search for beta thalassemia trait in India. Turkish J Hematol. 2012;29(4):427-9. https://doi.org/10.5505/tjh.2012.21703.

37. Thomas $C$, Thomas $L$. Biochemical markers and hematologic indices in the diagnosis of functional iron deficiency. Clin Chem. 2002;48(7):1066-76. https://doi.org/10.1093/clinchem/48.7.1066.

\section{Publisher's Note}

Springer Nature remains neutral with regard to jurisdictional claims in published maps and institutional affiliations.

\section{Submit your manuscript to a SpringerOpen ${ }^{\circ}$ journal and benefit from:}

- Convenient online submission

- Rigorous peer review

- Open access: articles freely available online

- High visibility within the field

- Retaining the copyright to your article

Submit your next manuscript at $\boldsymbol{\nabla}$ springeropen.com 